\title{
EFFECT OF PROBIOTICS, ORGANIC ACIDS OR THEIR MIX ON THE GROWTH PERFORMANCE OF STARTING COCKERELS
}

\author{
EFECTO DE PROBIÓTICOS, ÁCIDOS ORGÁNICOS O SU MEZCLA SOBRE \\ EL CRECIMIENTO Y PRODUCTIVIDAD DE POLLITOS
}

\author{
Fatufe, A.A ${ }^{* 1}$ and Matanmi, I.O. ${ }^{1}$ \\ ${ }^{1}$ Department of Animal Science. Obafemi Awolowo University. Ile-Ife. Nigeria. *aafatufe@oauife.edu.ng \\ ADDITIONAL KEYWORDS \\ Feed additives.

\section{Palabras clave adicionales} \\ Aditivos alimenticios.
}

\section{SUMMARY}

Two hundred and eighty eight 3 weeks old cockerels $(127.9 \pm 6.5 \mathrm{~g})$ were randomly assigned to 7 treatments for a 42 days feeding trial. A basal diet (whithout additives) was formulated (maize, soybean meal, groundnut cake and wheat bran). Probiotic (Lactobacillus acidophilus, Saccharomyces cerevisae and S. boulardii) was added to the basal diet at the expense of wheat bran at $0,0.05$ and $0.1 \%$ in diets I, II and III. Organic acids (formic and propionic) replaced the wheat bran at $0,0.2$ and $0.4 \%$ in diets I, IV and V. A mix of probiotics+acidifier replaced the wheat bran at $0.0+0.0,0.05+0.2$, and $0.1+0.4 \%$ in diets I, VI and VII. Increasing feed additive did not affect to final body weight, body weight gain, protein efficiency ratio and feed/gain ratio of starting chicken. Aditives at lower or upper levels of inclusion exert no influence on most performance criteria except on feed intake which was higher in birds fed a mix of probiotics and organic acids on diets VI and VII. Final body weight was highest on diet $\mathrm{VI}$ (711) and lowest on diet I (661), while feed/gain ratio was highest on diet VII (4.1) and lowest on diet III (3.8).

\section{RESUMEN}

Doscientos ochenta y ocho pollos de 3 semanas $(127,9 \pm 6,5 \mathrm{~g})$, fueron aleatoriamente asignados a 7 tratamientos para una prueba durante 42 días. Se formuló una dieta basal (maíz, harina de soja, torta de cacahuete y salvado de trigo). El probiótico (Lactobacillus acidophilus, Saccharomyces cerevisae y $S$. boulardii) fue añadido a la dieta basal a expensas del salvado de trigo a razón de 0; 0,05 y 0,1\% (dietas I, II y III). Los ácidos

Recibido: 26-6-08. Aceptado: 2-4-09. orgánicos (fórmico y propiónico) reemplazaron al salvado en proporciones de 0; 0,2 y $0,4 \%$ en las dietas I, IV y V. Una mezcla de probiótico y acidificante $(\%)$ de $0,0+0,0 ; 0,05+0,2$ y $0,1+0,4$ reemplazó al salvado en las dietas I, VI y VII. EI aumento de la concentración del aditivo no afectó al peso vivo final, ganancia de peso vivo, relación de eficacia proteica y relación pienso/ganancia de los pollos. Los aditivos a niveles altos o bajos de inclusión no ejercieron efecto sobre la mayoría de los criterios de productividad salvo ingestión de alimento que fue mayor en las aves que consumían mezcla de probióticos y ácidos orgánicos en las dietas VI y VII. El peso corporal final fue mayor (711) en la dieta VI y menor en la I (661), mientras que la razón pienso/ganancia de peso fue mayor en la dieta VII $(4,1)$ y menor en la III $(3,8)$.

\section{INTRODUCTION}

The continuous and routine usage of antibiotics in livestock feed has come under close scrutiny due to the residues left in animal products and the development of resistance of intestinal micro-organism to antibiotics in humans.

Short to medium length chain organic acids such as propionic, butyric, acetic, formic, lactic, malic, tartaric and citric acids when fed are believed to be bacteriostatic at low concentrations and bactericidal at high concentrations and their efficacy varies depending on the organic acid in question (Dibner and Buttin, 2002). Simon (2005) 


\section{FATUFE ANDMATANMI}

defined probiotics as viable microorganisms, which after sufficient oral intake, lead to beneficial effects for the host by modifying the intestinal microbio$t a$. The microorganisms used in animal feed are mainly bacterial strains of Gram-positive bacteria belonging to the genera of Lactobacillus, Enterococcus, Streptococcus, Bifidobacterium, Pediococcus, Bacillus and microscopic fungi such as strains of Saccharomyces cerevisiae (Stavric and Kornegay, 1995). The use of probiotics in broiler and pigs has been reported to show some promise in terms of improvement in body weight gain and feed efficiency (Stavric and Kornegay, 1995; Simon, 2005). Similarly organic acids have been reported to be beneficial in broilers and piglets (Lückstädt et al., 2004).

Cockerels are slow growing (male layer) birds usually raised for their meat and low carcass fatness. They respond well to dietary nutrient supply if fed diets needed for their optimal growth rates. It is however not known if slow growing animals such as cockerels could benefit from the growth promoting influence of probiotics and organic acids. The objective of this study was to evaluate the performance of starting cockerels fed either probiotics, organic acids or a mix of probiotics and organic acids using cockerels as a model animal for slow growing birds.

\section{MATERIALS AND METHODS}

Two hundred and eighty eight 3 weeks old black (Bovan Nera) cockerels with initial weight of $127.9 \pm 6.5 \mathrm{~g}$ were randomly assigned to seven dietary treatments in a complete randomised design. Birds on the control diet (diet I) were 72 birds ( 6 replicates of 12 birds each) while other treatments had 36 birds ( 3 replicates of 12 birds each). Birds were weighed and uniformly distributed to their respective pen on weight basis. Individual pen has a dimension of $1.5 \times 1.3 \mathrm{~m}$. Feed and water were also supplied unrestrictedly. Birds were individually weighed on weekly basis until the end of the experiment and experiment lasted for 6 weeks. Daily voluntary feed intakes were monitored.

Table I. Gross and chemical compositions of the experimental diets (\%). (Composición bruta y química de las dietas experimentales).

\begin{tabular}{|c|c|c|c|c|c|c|c|}
\hline Ingredients & Diet I ${ }^{1}$ & Diet II & Diet III & Diet IV & Diet V & Diet VI & Diet VII \\
\hline Maize & 50 & 50 & 50 & 50 & 50 & 50 & 50 \\
\hline Other ingredient ${ }^{2}$ & 40 & 40 & 40 & 40 & 40 & 40 & 40 \\
\hline Wheat bran & 10 & 9.95 & 9.9 & 9.8 & 9.6 & 9.75 & 9.5 \\
\hline Probiotics & 0 & 0.05 & 0.1 & - & - & 0.05 & 0.1 \\
\hline Acidifers & - & - & - & 0.2 & 0.4 & 0.2 & 0.4 \\
\hline \multicolumn{8}{|c|}{ Calculated analyses (\%) } \\
\hline $\mathrm{ME} \mathrm{kcal/kg}$ & 2831.5 & 2830.9 & 2830.2 & 2828.9 & 2826.3 & 2828.2 & 2825.0 \\
\hline Crude protein & 21.28 & 21.27 & 21.26 & 21.24 & 21.21 & 21.24 & 21.20 \\
\hline Crude fibre & 4.550 & 4.545 & 4.541 & 4.532 & 4.515 & 4.528 & 4.506 \\
\hline Lysine & 1.024 & 1.024 & 1.024 & 1.023 & 1.022 & 1.023 & 1.021 \\
\hline Threonine & 0.702 & 0.701 & 0.701 & 0.701 & 0.699 & 0.700 & 0.699 \\
\hline Methionine & 0.477 & 0.477 & 0.477 & 0.477 & 0.476 & 0.476 & 0.476 \\
\hline
\end{tabular}

${ }^{1}$ Analysed proximate values for the control diet (\%) were: dry matter 90.92 , crude protein 21.98 , crude ash 6.18 , ether extract 4.4 and crude fibre 3.82 .

${ }^{2}$ Ingredients quantity were same for the six diets in following proportion (\%): Groundnut meal 14.9; Soybean meal 12; Palm kernel meal 5.8; Fish meal 3.0; Oyster shell 1.5; Bone meal 2.0; Salt 0.25; DLMethionine 0.15; L-Lysine. $\mathrm{Hcl} 0.15$ and Premix 0.25.

Archivos de zootecnia vol. 60, núm. 229, p. 150. 
PROBIOTICS AND ORGANIC ACIDS IN COCKERELS

Table II. Effect of probiotics, organic acids or their mix on the growth performance of cockerel chickens during 4 to 9 weeks of age. (Efecto de los probióticos, ácidos orgánicos o sus mezclas sobre el crecimiento de pollitos entre las 4 y 9 semanas de edad).

\begin{tabular}{|c|c|c|c|c|c|c|c|c|c|c|}
\hline & Diet I & Diet II & DietIII & Diet IV & Diet V & Diet VI & Diet VII & \multicolumn{2}{|c|}{ Pooled SEM $p$} & $p$ (ANOVA) \\
\hline $\mathrm{N}$ & 6 & 3 & 3 & 3 & 3 & 3 & 3 & \multicolumn{2}{|c|}{ - } & - \\
\hline FBW & 661 & 627 & 662 & 675 & 674 & 711 & 694 & \multicolumn{2}{|c|}{6.70} & 0.090 \\
\hline IBW & 129 & 131 & 122 & 128 & 120 & 133 & 131 & \multicolumn{2}{|c|}{1.30} & 0.512 \\
\hline BWG & 12.7 & 11.9 & 12.9 & 13.0 & 13.2 & 13.8 & 13.4 & \multicolumn{2}{|c|}{6.60} & 0.129 \\
\hline $\mathrm{FI}$ & $50.6^{b}$ & $47.7^{\mathrm{b}}$ & $48.4^{b}$ & $49.5^{b}$ & $51.0^{\mathrm{b}}$ & $56.3^{\mathrm{a}}$ & $55.4^{\mathrm{a}}$ & \multicolumn{2}{|c|}{1.10} & 0.020 \\
\hline FCR & 3.996 & 4.052 & 3.783 & 3.803 & 3.867 & 4.097 & 4.135 & \multicolumn{2}{|c|}{0.05} & 0.607 \\
\hline PER & 1.178 & 1.164 & 1.244 & 1.239 & 1.233 & 1.201 & 1.187 & \multicolumn{2}{|c|}{4.80} & 0.585 \\
\hline \multicolumn{4}{|c|}{ Contrasts ( $p$ value) } & \multicolumn{2}{|c|}{ FBW } & BWG & $\mathrm{FI}$ & FCR & PER & \\
\hline \multirow{6}{*}{\multicolumn{4}{|c|}{$\begin{array}{l}\text { Probiotics effect: } 2,3,6,7 \text { vs. } 1,4,5 \\
\text { Acidifier effect: } 4,5,6,7 \text { vs. } 1,2,3 \\
\text { Interaction at high dose: } 1,7 \text { vs. } 3,5 \\
\text { Interaction at low dose: } 1,6 \text { vs. } 2,4 \\
\text { Probiotics vs. control } \\
\text { Acidifier vs. control }\end{array}$}} & \multirow{2}{*}{\multicolumn{2}{|c|}{$\begin{array}{l}0.411 \\
0.066\end{array}$}} & 0.568 & 0.823 & 0.400 & \multicolumn{2}{|c|}{0.421} \\
\hline & & & & & & 0.015 & 0.027 & 0.657 & 0.575 & \\
\hline & & & & \multicolumn{2}{|c|}{0.334} & 0.491 & 0.078 & 0.282 & \multicolumn{2}{|c|}{0.302} \\
\hline & & & & \multicolumn{2}{|c|}{0.063} & 0.154 & 0.059 & 0.645 & \multicolumn{2}{|c|}{0.134} \\
\hline & & & & \multirow{2}{*}{\multicolumn{2}{|c|}{0.353}} & 0.464 & 0.076 & 0.518 & \multicolumn{2}{|c|}{0.470} \\
\hline & & & & & 967 & 0.396 & 0.798 & 0.060 & \multicolumn{2}{|l|}{0.051} \\
\hline
\end{tabular}

$\mathrm{N}$ : replicates per treatment. Means with different superscripts in the same row are significantly different $(\mathrm{p}<0.05)$. FBW: Final body weight (g/bird); IBW: Initial body weight (g/bird); BWG: Body weight gain ( $g /$ bird/day); FI: Feed intake (g/bird/day); FCR: Feed conversion ratio; PER: Protein efficiency ratio.

A basal diet was formulated to meet the nutrient requirement of starting chicks using the NRC (1994) as a guide. The basal diet was based on maize, soybean meal, groundnut cake and wheat bran. The basal diet was fortified with synthetic amino acids to optimize amino acid balance. Composition of diets was calculated based on published values from NRC (1994). Table I shows the ingredient composition of the experimental diets. Probiotics replaced the wheat bran in diets I, II and III in proportion of $0,0.05$ and $0.1 \%$ in the basal diet. Probiotics preparation was declared to contain Lactobacillus acidophilus $\left(4.5 \times 10^{10}\right)$, Saccharomyces cerevisae $\left(1.25 \times 10^{11}\right)$ and S. boulardii $(3.0$ $\mathrm{x} 10^{10}$ ) c.f.u. per $\mathrm{kg}$ by the manufacturer. Acidifier also replaced the wheat bran in diets I, IV and V in proportion of $0,0.2$ and $0.4 \%$ in the basal diet. Acidifier contained a blend of formic and propionic acid. A mix of probiotics and acidifier ( $\%$ ) of 0.0 plus 0.0 , 0.05 plus 0.2 and 0.1 plus 0.4 respectively also replaced the wheat bran in the basal diet in diets I, VI and VII. Replacement was carried out on weight for weight basis.

Data were subjected to one way ANOVA procedure, contrasts analysis for probiotics effect, acidifier effect, interaction at high dose, interaction at low dose, probiotics $v s$. control and acidifier $v s$. control was carried out using the contrast option of the one way ANOVA (SPSS 13.0 for Windows).

\section{RESULTSANDDISCUSSION}

The performance characteristics of chicken are shown in table II. Starting cockerels did not respond to increasing feed additive concentration in final body weight, body weight gain, protein efficiency ratio and feed/gain ratio irrespective of the feed additive or their mix. Feed intake was higher in birds fed a mix of probiotics and organic acids on diets VI and VII compared to other treatments. Average daily feed intake was highest on diet VI (56 g) and least on diet II (48 g). Final body weight (g) was similarly highest on diet VI (711) and lowest on diet I (661), while feed/gain ratio was 
highest on diet VII (4.1) and least on diet III (3.8). Contrasts analysis for probiotics effect, acidifier effect, interaction at high dose, interaction at low dose and probiotics $v s$. control for all performance characteristics were not significant except for acidifier effect (table II). Contrasting the performance of birds on diets IV, V, VI and VII vs. I, II and III revealed that acidifier had a significant effect on body weight gain and feed intake.

The concentrations of probiotics used in the present study are within the range of that was recommended by its manufacturer and also within the threshold that has been reported to elicit improved performance in poultry (Stavric and Kornegay, 1995). Probiotics supplementation in the present study had no effect on growth performance and this is in agreement with other reports on probiotics in poultry and pigs (Stavric and Kornegay, 1995; Simon, 2005; Midilli et al., 2008). Midilli et al. (2008) fed 0.05\% probiotics (Bacillus licheniformis and $B$. subtilis) to broiler chicken for 42 days and observed no significant improvement in final body weight, body weight gain, feed intake, feed conversion ratio, carcass weight and carcass yield. Reports on the use probiotics and its attendant benefits in poultry have been generally inconclusive.

\section{REFERENCES}

Dibner, J.J. and Buttin P. 2002. Use of organic acids as a model to study the impact of gut microflora on nutrition and metabolism. J. Appl. Poultry Res., 11: 453-463.

Lückstädt, C., Senköylü, N., Akyürek, H. and Agma, A. 2004. Acidifier. A modern alternative for antibiotic free feeding in livestock production, with special focus on broiler production. Veterinarija ir Zootechnika, 27: 91-93.

Midilli, M., Alp, M., Kocabagli, N., Muglali, O.H., Turan, N., Yýlmaz, H. and Çakýr, S. 2008. Effects of dietary probiotic and prebiotic supplementation on growth performance and serum IgG concen-
Organic acids similarly did not have a significant influence on growth performance in cockerel chicks. There was a tendency for acidifier to improve body weight gain and feed intake but these responses were not large enough to cause overall significant effect in daily gain and final body weight. The concentrations of acidifier used in this study are within the range of those previously reported to be effective in promoting growth in young pigs and poultry (Lückstädt et al., 2004). Significant increase in body weight gain and less often in feed conversion has been reported from some studies with organic acids in broiler chicken fed with a blend of propionic and formic acid (Lückstädt et al., 2004) and fumaric acid.

Feeding a mix of probiotics and organic acids in this study resulted in marginal increase in daily weight gain and higher feed intake. Feeding a mix of probiotics and organic acid did not enhance performance, just as feeding individual feed additive separately. The data on growth rate and feed intakes observed in this study are within the range previously reported in cockerels of similar growth phase, age and body weight (Sanwo et al., 2006). Neither probiotics nor organic acids or their mix have any growth promoting effect in cockerels.

tration of broilers. S. Afr. J Anim. Sci., 38: 21-27. NRC. 1994. Nutrient Requirements of poultry. $9^{\text {th }}$ Ed. National Academy Press. Washington.

Sanwo, K.A., Iyayi, E.A. and Olubamiwa, A.O. 2006. Performance characteristics of cockerels fed graded levels of kolanut (Cola nitida) pod husk. Nigerian Poultry Sci. J., 4: 34-38.

Simon, O. 2005. Micro-organisms as feed additivesprobiotics. Adv. Pork Prod., 16: 161-167.

Stavric, S. and Kornegay, E.T. 1995. Microbial probiotics for pigs and poultry. In: Wallace and Chesson (eds). Biotechnology in animal feeds and animal feeding. VCH. New York. pp. 205-231. 